\title{
RESEARCH ON READINESS FOR JOB CREATION THROUGH ONE'S OWN AGRIBUSINESS STARTUP
}

\author{
Boško Vojnović, ${ }^{1}$ Vidoje Stefanović, ${ }^{2}$ Dragana Vojnovićc ${ }^{3}$, Milorad Perović $^{4}$
}

\begin{abstract}
Summary
This paper examines the problems of jobs, employment, staff hiring in the agriindustrial complex, job description and requirements, theoretical and practical job cost indicators, and the willingness of our people to create new jobs by starting up their own private agribusiness.

The results indicate a chronic lack of private funds necessary for every new business as well as the inevitability of borrowing. Potential entrepreneurs know the advantages and the disadvantages of solo and partnership business; however, they do not have any potential partners in sight. Almost a half of them have their own facilities and arable land etc. as a material base; however, they do not know what else is needed for a business to operate properly. In general, they understand the importance of education and training for any future business.
\end{abstract}

Key words: self-employment, agriculture, one's own business, job, agribusiness

JEL: $Q 22$

\section{Introduction}

Unemployment is becoming a pressing issue in both Serbia and Europe. The phrase "right to work" emerges as a moral and political demand with the labour movement of the 18th century during the capitalist mode of production which, on one hand, brought about new production power and wealth, and on the other hand, unemployment and poverty. Considering the present moment and the immense need for new jobs we have attempted to explore the possibilities of creating a private agribusiness. We have examined the problems

1 Boško Vojnović, Ph.D, Associate Professor, Higher School of Agriculture, Vojvode Putnika 56, 15000 Šabac, Serbia, Phone: +381 62675 966, E-mail: bosko_v@open.telekom.rs

2 Vidoje Stefanović, Ph.D, Full Professor, Faculty of Science, Višegradska street 33, University of Nis, 18000 Niš, Serbia, Phone: +381 631012 468, E-mail: widojes@yahoo.com

3 Dragana Vojnović, DMR, Trg Heroja 24, 11420 Smederevska Palanka, Serbia, Phone: +381 63 86845 62, E-mail: bosko_v@open.telekom.rs

4 Milorad Perović, M.Sc., HE Đerdap, Pop Stojanova Street no. 2a, 11000 Belgrade, Serbia, Phone: +381 1138110 182,+381 63200 182, E-mail: milorad.perovic@djerdap.rs

EP 2014 (61) 2 (397-408) 
of hiring people in agriculture, economical and theoretical costs of jobs and our willingness to start up an agribusiness. Having in mind the unemployment rate in the Republic of Serbia this research is of great importance. According to the National Employment Service there are more than 800.000 unemployed waiting for a job. The actual number is probably even higher. Roughly the same number of people work in the public sector which is a huge burden for the economy, while there are only about million people working in the real sector. Therefore, a conclusion may be drawn that the only way to find a job is by self-employment. Therefore, we conducted a practical study on a sample of people situated in the following boroughs: Šabac, Ruma, Subotica, Novi Sad, Bogatić, Loznica, and for a smaller part in Belgrade. The research encompassed the wider area of Macvanski County because in that area, people traditionally work in the agricultural production. Also, the survey results may be relevant for other agricultural counties in the Republic of Serbia.

\section{Methodology}

The method used was interview and the sample was random. The research focused on the cities the interviewers live in. The interviews were carried out by the first year professors and students of the department for specialized studies at the School of Agriculture in Šabac as a part of the course „Outlines of Agri-management“ in late 2010 and early 2011. The interview included all the criteria we held important for the insight in the willingness for any new agribusiness enterprise.

A working hypothesis: the basic hypothesis is to find out whether (or not) people in Serbia are ready to start their own agribusiness. In this case, the problem of unemployment is clearly set, as the other one related to certain elements. Money, partners, buyers, suppliers, equipment, legal regulation was some of the more important criteria.

The processing of survey results is related to certain thematic fields linked with the hypothesis.

The interview questions were inspired by the test (How to start, run and stay in business) or Are You Ready to Start Your Business? The original authors are G. Kishel and P. Kishel (Kishel, Kishel, 1993). The questions are substantially modified to suit the needs of the research in the field of agriculture. The practical results are organized in tables.

\section{Unemployment and staff hiring for the agricultural complex}

Employment defines the situation where a society member capable of work performs a certain beneficial activity independently or with others which in return provide him/her the means they use to satisfy their own needs and obligations (Vojnovic et al., 2013).

Employment is simultaneously a component of economic development and an indicator of the present level of economic development and it represents one of the constant and primary goals. When considering the problem of unemployment, besides the present level of economic development, one should take into account the specific characteristics of the country or the industry and the period in question. The base for any kind of employment represents the opportunity for work and it is twofold: 
- the capable and those who want to work have their own business or,

- the access to an existing organized business.

The former or private business has the advantage when considering the economy circumstances related to the employment possibilities in some ,state agribusiness““.

It is no longer disputed that the efficiency of modern development in general, and agribusiness in particular cannot be based only on the material components, but more than ever on the entrepreneurial. The problem of staff hiring in the agri-industrial complex started in the 50s of the last century when good farmers were transformed into bad industrial workers. Many of them were left with one foot in the countryside. That gave rise to many controversial ideas that these so-called ,halvings" were more useful to industrial development, and less harmful to the development of the agri-industrial. For the period from 2005 to 2009 the agri-industrial sector recorded an annual production growth of about 1,1\% unlike the total industrial production that recorded a decrease of about 0,4\% annually. In 2009 the annual agri-industrial production decline in Serbia was 7,4\%, while the total decline in industrial production was a bit severe $12 \%$ (Nikolic et al., 2010).

When considering the problems of staff hiring for the agricultural complex, we have to emphasize that the problems are prominent and that should raise concern. For the interest of potential candidates for agribusiness to be at least similar to the interest for other industries, we have to create the conditions that would keep the young in rural areas. The study also provides information on the role of agribusiness employment in rural areas. The Role of Agribusiness in Maintenance of Future Rural Employment in Latvia (Krievina et al., 2013).

The entrepreneurial development in rural areas has a vast untapped potential for the economic strength of these areas and offers a real chance to increase employment of the local population, which generally find jobs harder. The very diversification of the rural life is a breath of fresh air because it sparks interest in people to remain in the countryside (Cvijanovic et al., 2011).

The conditions, costs, and profitability of a newly created job are very important for the beginning of a private business. This question is a multi-layered one; thus, it is important for the employment policy, let alone the whole social and economic system (Stefanovic, 1991).

It is even more important for the agricultural sector because such changes have occurred that there is no more a distinguishable difference between the primary and the processing sector in terms of labour or capital-intensity. It has to be taken into account that, apart from the demographic component, several more components have a crucial role in increasing the overall level of employment: the costs of a new job and the available accumulations and knowledge. Besides technical and economic factors, social and political factors influence the costs of a job (Stefanovic et al., 2011).

From the standpoint of the agricultural businessman as an individual holder of a business, the costs of a job for him and his staff represent the input of material, financial and other elements at high risks to the survival of a potential entrepreneurial venture. 
The employment policy in general, including the agricultural complex, should take into account an increased number of employees with university education. This process is already in a full sweep in highly developed countries (Simic et al., 2010).

Therefore, we can conclude that the employment policy in general, and especially in the agricultural complex, should not be the matter of the current trends and aspirations but a well-designed initiative of all subjects that have more or less directed the course of not only the development of the agri-industrial complex, but the overall social economic development.

\section{Results and Discussion}

Certain survey results will be presented according to thematic fields, in logical order and linked with the hypothesis

Table 1. Examinee data

\begin{tabular}{|l|c|c|}
\hline Examinee data & Frequency & \% \\
\hline Age & 3 & 2 \\
\hline 20 or under & 75 & 47 \\
\hline $21-30$ & 27 & 17 \\
\hline $31-40$ & 34 & 13 \\
\hline $41-50$ & 21 & 51 \\
\hline 51 and over & \multicolumn{2}{|c|}{} \\
\hline Gender & 82 & 49 \\
\hline Male & 78 & 14 \\
\hline Female & \multicolumn{2}{|c|}{} \\
\hline Work experience & 22 & 34 \\
\hline No work experience & 55 & 16 \\
\hline 5 years or less & 25 & 11 \\
\hline $6-10$ years & 17 & 9 \\
\hline $11-15$ years & 15 & 16 \\
\hline $16-20$ years & 26 & - \\
\hline 20 years or more & \multicolumn{3}{|c|}{} \\
\hline Education & 0 & 3 \\
\hline No education & 5 & 30 \\
\hline Elementary & 66 & 3 \\
\hline Secondary & 4 & 13 \\
\hline Upper secondary & 4 & 35 \\
\hline Post-secondary non-tertiary education & 20 & 3 \\
\hline Short-cycle tertiary education & 56 & \\
\hline Bachelor & 5 & \\
\hline Master or Doctoral & \multicolumn{3}{|c|}{} \\
\hline
\end{tabular}

Source: own research, 2011.

Most of the people interviewed in this study are of younger age. $64 \%$ of the examinees are between 20 and 40 years old, while the gender structure is more balanced. In terms of work experience, $34 \%$ has 5 years or less, $16 \% 6$ to 10 , and $16 \%$ more than 20 . In terms of education $40 \%$ has secondary education, and $38 \%$ has higher education including master or doctoral education. 
Table 2. The most important data about agri-entrepreneurs

\begin{tabular}{|c|c|c|c|c|c|c|}
\hline Questions & Yes & $\%$ & No & $\%$ & Undecided & $\%$ \\
\hline \multicolumn{7}{|c|}{ Agri-entrepreneur } \\
\hline $\begin{array}{l}\text { Do you think that you can run a successful } \\
\text { agribusiness and stay in it? }\end{array}$ & 83 & 52 & 42 & 26 & 35 & 22 \\
\hline $\begin{array}{l}\text { Are you ready to give your best in your agribusiness, } \\
\text { even though you haven't any guarantees it will be } \\
\text { successful? }\end{array}$ & 77 & 48 & 60 & 38 & 23 & 14 \\
\hline $\begin{array}{l}\text { Have you ever worked in a business similar to the } \\
\text { one you want to start? }\end{array}$ & 61 & 38 & 95 & 59 & 4 & 3 \\
\hline Do you have any previous training in agribusiness? & 36 & 23 & 123 & 76 & 1 & 1 \\
\hline $\begin{array}{l}\text { Have you explored enough the business idea you } \\
\text { wish to realize in agribusiness? }\end{array}$ & 46 & 29 & 99 & 62 & 15 & 9 \\
\hline
\end{tabular}

Source: own research, 2011.

$52 \%$ of potential agri-entrepreneurs think they can start their own business; moreover, they think they can stay in it. They are willing to commit themselves, although the risks are high, which indicates the presence of entrepreneurial spirit among our people. Most of them do not have any experience in this line of work, no previous training nor any business idea they would like to realize in agribusiness.

Table 3. Important financial elements for starting an agribusiness

\begin{tabular}{|c|c|c|c|c|c|c|}
\hline Questions & Yes & $\%$ & No & $\%$ & Undecided & $\%$ \\
\hline \multicolumn{7}{|c|}{ Finances } \\
\hline $\begin{array}{l}\text { Do you possess any saving you would like to invest } \\
\text { into your agribusiness? }\end{array}$ & 37 & 23 & 110 & 69 & 13 & 8 \\
\hline $\begin{array}{l}\text { Are you familiar with the amount of money you } \\
\text { can receive in the form of loans from various } \\
\text { financial institutions that support the development of } \\
\text { agribusiness? }\end{array}$ & 58 & 36 & 88 & 55 & 14 & 9 \\
\hline $\begin{array}{l}\text { Are you aware of any sources from which you can } \\
\text { make up for the lack of funds? }\end{array}$ & 58 & 36 & 96 & 60 & 6 & 4 \\
\hline $\begin{array}{l}\text { Do you assume what would be your annual salary } \\
\text { and profits from a potential agribusiness? }\end{array}$ & 36 & 23 & 92 & 57 & 32 & 20 \\
\hline $\begin{array}{l}\text { Are you willing, if necessary, to live on a lower } \\
\text { income and lower profits? }\end{array}$ & 92 & 57 & 56 & 35 & 12 & 8 \\
\hline $\begin{array}{l}\text { Have you contacted any bank regarding your plans in } \\
\text { agribusiness? }\end{array}$ & 18 & 11 & 137 & 86 & 5 & 3 \\
\hline
\end{tabular}

Source: own research, 2011.

In this paper we have already said that a job generates costs. The interview results show that $69 \%$ of the examinees do not have any savings to start their own business. Therefore, the necessary funds must be obtained from other sources.

Moreover, $60 \%$ of them do not even know how much of the start-up capital they need nor they are familiar with any sources they can use to compensate for the lack of funds. Therefore, their monthly and annual salary is an unknown. However, they are more than 
ready to live on a small income and they explain this with the fact that a small income that can improve over time is better than none. Also, they have never had any contacts with financial institutions that loan money.

Table 4. Analysis of potential partners and buyers

\begin{tabular}{|c|c|c|c|c|c|c|}
\hline Questions & Yes & $\%$ & No & $\%$ & Undecided & $\%$ \\
\hline \multicolumn{7}{|c|}{ Partner } \\
\hline $\begin{array}{l}\text { Given that you don't have enough funds and } \\
\text { knowledge to start your agribusiness, do you have } \\
\text { any potential partner? }\end{array}$ & 56 & 35 & 86 & 54 & 18 & 11 \\
\hline $\begin{array}{l}\text { Are you familiar with the advantages and } \\
\text { disadvantages of solo and partnership business? }\end{array}$ & 86 & 54 & 53 & 33 & 21 & 13 \\
\hline $\begin{array}{l}\text { Have you discussed with any legal experts the legal } \\
\text { matters related to your partnership? }\end{array}$ & 29 & 18 & 126 & 79 & 5 & 3 \\
\hline \multicolumn{7}{|l|}{$\begin{array}{ll} & \text { Buyers } \\
\end{array}$} \\
\hline Have you identified and segmented the market? & 49 & 31 & 95 & 59 & 16 & 10 \\
\hline $\begin{array}{l}\text { Is there a need for agricultural products or services } \\
\text { that your potential business could offer? }\end{array}$ & 80 & 49 & 52 & 33 & 28 & 18 \\
\hline Have you identified your future customers? & 80 & 50 & 56 & 35 & 24 & 15 \\
\hline Do you understand their needs and demands? & 76 & 47 & 59 & 37 & 25 & 16 \\
\hline $\begin{array}{l}\text { Will your products/services be competitive in terms } \\
\text { of price and quality? }\end{array}$ & 68 & 42 & 56 & 35 & 36 & 23 \\
\hline $\begin{array}{l}\text { Have you chosen an appropriate location for your } \\
\text { business that is also acceptable to your customers? }\end{array}$ & 66 & 41 & 51 & 32 & 43 & 27 \\
\hline
\end{tabular}

Source: own research, 2011.

Potential entrepreneurs, who do not possess the necessary funds, have neither any potential partners nor any knowledge of the legal issues related to that and that fact should raise concern. However, they are well aware of the advantages and disadvantages of solo and partnership business.

Half of the interviewed people think that there is a real demand for agricultural products. They can identify future customers, they understand their needs and demands, but they have not identified or segmented any potential market.

Table 5. Availability of premises and equipment

\begin{tabular}{|c|c|c|c|c|c|c|}
\hline Questions & Yes & $\%$ & No & $\%$ & Undecided & $\%$ \\
\hline \multicolumn{7}{|c|}{ Premises } \\
\hline $\begin{array}{l}\text { Have you found the appropriate premises and other } \\
\text { resources for your potential agribusiness? }\end{array}$ & 86 & 54 & 53 & 33 & 21 & 13 \\
\hline $\begin{array}{l}\text { Could you organize the offices at will without any } \\
\text { additional expenses? }\end{array}$ & 77 & 48 & 57 & 36 & 26 & 16 \\
\hline $\begin{array}{l}\text { Does the building you plan to use come with } \\
\text { any other additional conveniences (a parking lot, } \\
\text { maintenance, security)? }\end{array}$ & 58 & 36 & 88 & 55 & 14 & 9 \\
\hline $\begin{array}{l}\text { Have you consulted any legal experts on the matters } \\
\text { of leasing or purchasing any offices or buildings? }\end{array}$ & 21 & 13 & 131 & 82 & 8 & 5 \\
\hline
\end{tabular}




\begin{tabular}{|c|c|c|c|c|c|c|}
\hline Questions & Yes & $\%$ & No & $\%$ & Undecided & $\%$ \\
\hline \multicolumn{7}{|c|}{ Premises } \\
\hline $\begin{array}{l}\text { Have you compared the amounts of money } \\
\text { necessary for leasing or purchasing any premises? }\end{array}$ & 60 & 38 & 94 & 58 & 6 & 4 \\
\hline \multicolumn{7}{|l|}{ Equipment } \\
\hline $\begin{array}{l}\text { Do you know what kind of equipment is necessary } \\
\text { for agribusiness? }\end{array}$ & 52 & 33 & 99 & 61 & 9 & 6 \\
\hline Could a purchase of used equipment reduce costs? & 80 & 50 & 56 & 35 & 24 & 15 \\
\hline
\end{tabular}

Source: own research, 2011.

More than a half of them do not have any appropriate premises or any other resources. They haven't consulted any legal experts on the matter. In fact, they don't even know the cost to lease. The necessary material and financial assets are also unknown to them.

Table 6. Knowing the suppliers

\begin{tabular}{|l|c|c|c|c|c|c|c|}
\hline \multicolumn{1}{|c|}{ Questions } & Yes & $\%$ & No & $\%$ & Undecided & $\%$ \\
\hline \multicolumn{2}{|c|}{ Suppliers } & 62 & 33 & 73 & 45 & 25 & 16 \\
\hline $\begin{array}{l}\text { Do you know what supplies are necessary for your } \\
\text { agribusiness to be successful? }\end{array}$ & 51 & 32 & 84 & 52 & 25 & 16 \\
\hline $\begin{array}{l}\text { Do you know the amount of stock necessary for the } \\
\text { beginning of your agri-entrepreneurial venture? }\end{array}$ & 46 & 29 & 100 & 62 & 14 & 9 \\
\hline $\begin{array}{l}\text { Have you identified and defined suppliers depending } \\
\text { on whether their prices are affordable or not? }\end{array}$ & 53 & 33 & 99 & 62 & 8 & 5 \\
\hline $\begin{array}{l}\text { Is there any difference in prices depending on } \\
\text { whether you pay in cash or with a delay period? }\end{array}$ & & & & \\
\hline
\end{tabular}

Source: own research, 2011.

What encourages is the fact that the examinees can identify and define potential suppliers and that they are aware of the benefits of paying in cash as opposed to delayed payments.

Table 7. Administration and payment system

\begin{tabular}{|c|c|c|c|c|c|c|}
\hline Questions & Yes & $\%$ & No & $\%$ & Undecided & $\%$ \\
\hline \multicolumn{7}{|c|}{ Administration and payment system } \\
\hline $\begin{array}{l}\text { Have you chosen an appropriate system of recording } \\
\text { income, expenses, assets and liabilities? }\end{array}$ & 53 & 33 & 98 & 61 & 9 & 6 \\
\hline $\begin{array}{l}\text { Have you chosen a system of keeping track the stock } \\
\text { and maintaining it on an optimal level? }\end{array}$ & 50 & 31 & 101 & 63 & 9 & 6 \\
\hline $\begin{array}{l}\text { Are you familiar with the methodology of tax and } \\
\text { fee calculation? }\end{array}$ & 63 & 39 & 86 & 54 & 11 & 7 \\
\hline $\begin{array}{l}\text { Do you know which financial statements you must } \\
\text { prepare? }\end{array}$ & 62 & 39 & 84 & 52 & 14 & 9 \\
\hline $\begin{array}{l}\text { Do you know how to interpret and use financial } \\
\text { statements? }\end{array}$ & 68 & 43 & 83 & 51 & 9 & 6 \\
\hline
\end{tabular}

Source: own research, 2011.

In this section, majority of questioners said that they have not decided on a system for recording the income, or the system for keeping track of the stock. Also, most of them are 
not familiar with the methodology for calculating taxes, or which financial statements to prepare and most of the, do not know how to interpret financial statements.

Table 8. Knowing legislation

\begin{tabular}{|c|c|c|c|c|c|c|}
\hline Questions & Yes & $\%$ & No & $\%$ & Undecided & $\%$ \\
\hline \multicolumn{7}{|c|}{ Legislation } \\
\hline $\begin{array}{l}\text { Do you know what licenses and permits you need } \\
\text { to start any potential agribusiness? }\end{array}$ & 40 & 25 & 106 & 66 & 14 & 9 \\
\hline $\begin{array}{l}\text { Are you familiar with the legislation in the area of } \\
\text { agribusiness? }\end{array}$ & 42 & 26 & 103 & 65 & 15 & 9 \\
\hline $\begin{array}{l}\text { Do you know any experts that could advise you on } \\
\text { the legal matters? }\end{array}$ & 87 & 54 & 62 & 39 & 11 & 7 \\
\hline Have you opted for any insurance company? & 26 & 16 & 127 & 80 & 7 & 4 \\
\hline
\end{tabular}

Source: own research, 2011.

Most of them, $66 \%$ actually, know what permits are required for a potential agribusiness and are familiar with the legislation, although they do not know any particular person that can advise them and prepare the necessary documentation. $80 \%$ of the interviewed would rather use the services of an insurance company.

Table 9. Purchasing a firm - business

\begin{tabular}{|c|c|c|c|c|c|c|}
\hline Questions & Yes & $\%$ & No & $\%$ & Undecided & $\%$ \\
\hline \multicolumn{7}{|c|}{ If you are purchasing a firm - business } \\
\hline $\begin{array}{l}\text { Do you know the pros and cons for purchasing an } \\
\text { existing agribusiness? }\end{array}$ & 77 & 48 & 65 & 41 & 18 & 11 \\
\hline $\begin{array}{l}\text { Do you know the real reasons why the current } \\
\text { owner is selling his firm? }\end{array}$ & 99 & 62 & 48 & 30 & 13 & 8 \\
\hline $\begin{array}{l}\text { Have you compared the costs of purchasing an } \\
\text { agribusiness with the costs of starting up a new } \\
\text { one?? }\end{array}$ & 123 & 77 & 23 & 14 & 14 & 9 \\
\hline $\begin{array}{l}\text { Do you know what others think about the business } \\
\text { you wish to purchase? }\end{array}$ & 129 & 81 & 24 & 15 & 7 & 4 \\
\hline Have you talked with the business suppliers? & 136 & 85 & 14 & 9 & 10 & 6 \\
\hline
\end{tabular}

Source: own research, 2011.

When purchasing an existing business, given that they are not to start their own, the reasons for the sale are very important. They should compare the profitability of both scenarios taking into account the opinion of more competent people. 
Table 10. Advertising, prices, sale and procurement

\begin{tabular}{|c|c|c|c|c|c|c|}
\hline Questions & Yes & $\%$ & No & $\%$ & Undecided & $\%$ \\
\hline \multicolumn{7}{|l|}{ Advertising } \\
\hline $\begin{array}{l}\text { Have you decided which media to use for } \\
\text { advertising: newspapers, direct sale, radio, } \\
\text { presentations, TV? }\end{array}$ & 81 & 51 & 53 & 33 & 26 & 16 \\
\hline $\begin{array}{l}\text { Is there anyone who could help you select the } \\
\text { appropriate type of advertising? }\end{array}$ & 91 & 56 & 52 & 33 & 17 & 11 \\
\hline Have you analysed competitors' advertising? & 60 & 38 & 92 & 57 & 8 & 5 \\
\hline \multicolumn{7}{|c|}{ Prices } \\
\hline $\begin{array}{l}\text { Do you know how to set prices for your products } \\
\text { or services? }\end{array}$ & 84 & 52 & 60 & 38 & 16 & 10 \\
\hline $\begin{array}{l}\text { Have you developed any price strategy for certain } \\
\text { markets? }\end{array}$ & 43 & 27 & 112 & 70 & 5 & 3 \\
\hline \multicolumn{7}{|c|}{ Sale } \\
\hline $\begin{array}{l}\text { Do you have any basic techniques in selling } \\
\text { agricultural products? }\end{array}$ & 57 & 36 & 76 & 47 & 27 & 17 \\
\hline Could you persuade customers to buy your products? & 99 & 62 & 37 & 23 & 24 & 15 \\
\hline $\begin{array}{l}\text { Are you familiar with the benefits you product has } \\
\text { to offer to a potential customer? }\end{array}$ & 97 & 61 & 39 & 24 & 24 & 15 \\
\hline $\begin{array}{l}\text { Are you well acquainted with the product you want } \\
\text { to sell? }\end{array}$ & 102 & 64 & 39 & 24 & 19 & 12 \\
\hline \multicolumn{7}{|c|}{ Procurement } \\
\hline Have you selected your suppliers? & 47 & 29 & 105 & 66 & 8 & 5 \\
\hline $\begin{array}{l}\text { Do you have a plan that includes your stock, the } \\
\text { time and the amount of your procurement? }\end{array}$ & 49 & 31 & 100 & 62 & 11 & 7 \\
\hline
\end{tabular}

Source: own research, 2011.

They have a certain notion of the type and the importance of advertising, although they did not say whether they would analyse any competitors' advertising. The fact that more than a half of the examinees do not know how to set the price for their products represents a real problem.

In sale they lack the basic knowledge, but they have the ability to persuade a potential customer to buy. The indecisiveness regarding supplier selection and the lack of any stock and procurement plan represent a real problem because $60 \%$ of the interviewed had many unresolved questions in that area.

Table 11. About the staff

\begin{tabular}{|c|c|c|c|c|c|c|}
\hline Questions & Yes & $\%$ & No & $\%$ & Undecided & $\%$ \\
\hline \multicolumn{7}{|c|}{ Staff } \\
\hline $\begin{array}{l}\text { When you want to hire someone, do you know } \\
\text { how to select an adequate person? }\end{array}$ & 114 & 71 & 26 & 16 & 20 & 13 \\
\hline $\begin{array}{l}\text { What is the desired profile of the person you want } \\
\text { to hire? }\end{array}$ & 119 & 74 & 24 & 15 & 17 & 11 \\
\hline Do you know how much you should pay him/her? & 81 & 50 & 52 & 33 & 27 & 17 \\
\hline Do you plan any training for your staff? & 86 & 54 & 56 & 35 & 18 & 11 \\
\hline
\end{tabular}

Source: own research, 2011. 
The employment and staff selection results show that potential employers know how to make selection, how much to pay employees, and how important are training and education to employees.

Table 12. Additional questions

\begin{tabular}{|l|c|c|c|c|c|c|c|c|c|}
\hline \multicolumn{1}{|c|}{ Questions } & Yes & $\mathbf{\%}$ & No & $\mathbf{\%}$ & Undecided & $\%$ \\
\hline Have you talked about your idea with the family members and do you have their support? \\
\hline $\begin{array}{l}\text { Are you willing to completely commit yourself to } \\
\text { agribusiness? }\end{array}$ & 75 & 47 & 82 & 51 & 3 & 2 \\
\hline $\begin{array}{l}\text { Are you prepared and do you have the knowledge } \\
\text { to start making a business plan? }\end{array}$ & 77 & 48 & 50 & 31 & 33 & 21 \\
\hline $\begin{array}{l}\text { Have you talked about your idea with the family } \\
\text { members and do you have their support? }\end{array}$ & 62 & 39 & 66 & 41 & 32 & 20 \\
\hline
\end{tabular}

Source: own research, 2011.

Another concern is that about $50 \%$ of the interviewed people had not talked with the family members about a potential agribusiness. The fact that they don't know how to make a business plan is yet another problem.

\section{Conclusion}

The survey results of the Readiness for Job Creation through one's own Agribusiness Start-up in Serbia of a certain area, come down to several basic elements:

- People are ready to start and run their own agribusiness despite the fact that success is not guaranteed.

- Most of the examinees do not have own financial resources to start any sort of venture. Also, most of them do not know a potential partner for that venture, but are aware of the advantages one's own business provides.

- Half of the examinees guessed their future buyers but did not segment the potential market.

- Potential agri-entrepreneurs can secure adequate premises for starting an agribusiness and can decide which is better, to rent or to buy their own premises.

- Potential agri-entrepreneurs do not know much about suppliers and procurement conditions.

- Examinees do not know legislative, but they know individuals who can help them with this issue.

- Should they buy mobile agribusiness, the examinee would know what are advantages and disadvantages of starting such a business.

- In most cases potential agri-entrepreneurs did not talk about such an idea with their family members, and half of them are ready to completely dedicate themselves to agribusiness.

The hypothesis about the readiness for job creation through one's own agribusiness start-up can conditionally be confirmed and it goes like this: potential agri entrepreneurs are ready to create jobs through their own agribusiness start-ups but should first go through a series of trainings for entrepreneurs. 


\section{Literature}

1. Cvijanović, J., Vojnović, B., Lazić, J. (2011): Istraživanje zainteresovanosti žena za preduzetništvo u agrobiznisu, Ekonomika poljoprivrede, IEP, Beograd, Srbija, Vol. 58, no. 1, str. 67-79.

2. Kishel, G., Kishel, P. (1993): How to start, run and stay in Business, John Wiley \& Sons inc, New York, USA.

3. Nikolić I., Filipović, S., Miljković, M. (2010): Potencijali poljoprivredno-prehrambenog sektora Srbije, Industrija, Ekonomski institut, Beograd, Srbija, Vol. 38, br. 4, str. 203222.

4. Simić, D., Vojnović, B., Grujić, D. (2010): Društvena odgovornost kompanija u agrobiznisu, Savremena poljoprivreda, Poljoprivredni fakultet, Novi Sad, Srbija, Vol. 59, no. 5, str. 494-502.

5. Stefanović, V., Grujić, D., Vojnović, B. (2011): Kadrovska raskršća srpskog agrara, Monografija, PMF, Univerzitet u Nišu, Niš, Srbija.

6. Stefanović, V. (1991): Razvoj kadrova u privredi - na primeru agroindustrijskog kompleksa, IP Gradina, Niš, Srbija.

7. Vojnović, B., Stefanović, V., Vojnović, D. (2011): Research documentation, Higher agricultural School, Šabac, Serbia.

8. Vojnović, B., Grujić, D., Grujić, S. (2013): Poljoprivreda, turizam i saobraćaj u funkciji privrednog razvoja, Institut za ekonomiku poljoprivrede, Beograd, Srbija.

9. Krievina, A., Leimane, I., Miglavs, A. (2013): The Role of Agribusiness in Maintenance of Future Rural Employment in Latvia, Proceedings of the Latvia University of Agriculture, Jelgava, Latvia, Vol. 28, no. 1, pp. 38-47. 


\title{
ISTRAŽIVANJE O SPREMNOSTI OTVARANJA RADNIH MESTA POKRETANJEM SOPSTVENOG AGROBIZNISA
}

\author{
Boško Vojnović, ${ }^{5}$ Vidoje Stefanović, ${ }^{6}$ Dragana Vojnovič ${ }^{7}$, Milorad Perovic ${ }^{8}$
}

\begin{abstract}
Rezime
U radu se istražuju problemi radnih mesta, zaposlenosti, angažovanja kadrova za agroindustrijski kompleks, šta čini radno mesto, teorijski i praktični indikatori cene radnog mesta i spremnost naših ljudi za otvaranje radnih mesta ulaskom u sopstveni agrobiznis. Rezultati ukazuju na hroničan nedostatak ličnih sredstava za startovanje biznisa $i$ na neizbežnost zaduživanja. Potencijalni agropreduzetnici razgraničavaju prednosti $i$ nedostatke solo i ortačkog biznisa, ali nemaju u vidu potencijalnog partnera. Materijalnu bazu za stvaranje radnog mesta u vidu sopstvenog prostora, obradivog zemljišta $i$ slično, ima skoro polovina ispitanih, ali nemaju saznanja koliko je pored toga još sredstava potrebno za funkcionisanje biznisa. Uglavnom shvataju značaj treninga i obuke za kreiranje budućeg posla.
\end{abstract}

Ključne reči: samozapošljavanje, poljoprivreda, sopstveni posao, radno mesto, agrobiznis.

5 Prof. dr Boško Vojnović, vanredni profesor, Visoka poljoprivredna škola, Vojvode Putnika 56, 15000 Šabac, Srbija, Telefon: +381 62675 966, E-mail: bosko_v@,open.telekom.rs

6 Prof. dr Vidoje Stefanović, redovni profesor, Prirodno matematički fakultet, Višegradska 33, Univerzitet u Nišu, 18000 Niš, Srbija, Telefon: +381 631012 468, E-mail: widojes@yahoo.com

7 Dragana Vojnović, DMR, Trg Heroja 24, 11420 Smederevska Palanka, Srbija, Telefon: +381 6386845 62, E-mail: bosko v@,open.telekom.rs

8 Mr Milorad Perović, HE Đerdap, Pop Stojanova 2a, 11000 Beograd, Srbija, Telefon: +381 1138110 182, +381 63200 182, E-mail: milorad.perovic@djerdap.rs 